\title{
Review Article \\ Diabetes, Endothelial Dysfunction, and Vascular Repair: What Should a Diabetologist Keep His Eye on?
}

\author{
V. Altabas \\ Department for Endocrinology, Diabetes and Metabolic Diseases "Mladen Sekso", Clinic for Internal Medicine, \\ University Hospital Center "Sestre Milosrdnice", 10000 Zagreb, Croatia
}

Correspondence should be addressed to V. Altabas; velimir.altabas@gmail.com

Received 17 September 2014; Accepted 13 January 2015

Academic Editor: Nikolaos Papanas

Copyright (C) 2015 V. Altabas. This is an open access article distributed under the Creative Commons Attribution License, which permits unrestricted use, distribution, and reproduction in any medium, provided the original work is properly cited.

Cardiovascular complications are the most common complications of diabetes mellitus. A prominent attribute of diabetic cardiovascular complications is accelerated atherosclerosis, considered as a still incurable disease, at least at more advanced stages. The discovery of endothelial progenitor cells (EPCs), able to replace old and injured mature endothelial cells and capable of differentiating into healthy and functional endothelial cells, has offered the prospect of merging the traditional theories on the pathogenesis of atherosclerosis with evolving concepts of vascular biology. The literature supports the notion that EPC alterations are involved in the pathogenesis of vascular diseases in diabetics, but at present many questions remain unanswered. In this review the aspects linking endothelial progenitor cells to the altered vascular biology in diabetes mellitus are discussed.

\section{Introduction}

Cardiovascular complications are the most common and devastating complications of diabetes mellitus; they are a major cause of hospital admissions and leading cause of death among diabetic patients $[1,2]$. A prominent attribute of diabetic cardiovascular complications is accelerated atherosclerosis, which is associated with oxidative stress, insulin resistance, and the metabolic syndrome [3, 4]. Current knowledge suggests that endothelial injury and dysfunction occur as the initial event in the pathogenesis of atherosclerosis, followed by platelet adhesion and aggregation [5]. Overproduction of cytokines and other inflammation mediators stimulates migration and proliferation of smooth muscle cells in the vascular intima and deposition of extracellular matrix molecules like collagen and elastin, leading to plaque expansion and fibrous cap formation [6, 7]. Fibrous caps may weaken and rupture eventually, exposing the underlying extremely thrombogenic tissues. Plaque rupture induces further thrombus formation and release of more inflammatory mediators, causing continued progression of the atherosclerotic plaque, finally resulting in luminal narrowing and/or occlusion. Dramatic events like myocardial infarction, ischemic stroke, or critical ischemia of peripheral tissues may appear, depending of the anatomic site of the injured vessel $[8,9]$. With increasing knowledge about the pathogenesis of atherosclerosis, hope that human atheromata can regress has evolved, but over time this idea met considerable skepticism. Resistance to concepts of lesion regression was enhanced by the fact that advanced atheromata in humans and in animals contain necrosis, calcification, and fibrosis, giving an impression of still irreparable events [10-13].

The discovery of a cell subgroup of myeloid origin, able to replace old and injured mature endothelial cells and capable of differentiating into healthy and functional endothelial cells, challenged skeptics. Those cells, named endothelial progenitor cells (EPC), have offered the prospect of merging the traditional theories on the pathogenesis of atherosclerosis with evolving concepts of atherosclerosis regression. Indeed, it seems that these progenitor cells are able to repair the injured vessel wall and to enhance neovascularization of ischemic tissues [14-16].

On the contrary, reduced EPC levels are associated with more serious endothelial dysfunction and elevated risk of adverse cardiovascular events, compatible with the concept that impaired EPC-mediated vascular repair allows further progression of vascular disease [17]. 
This applies in particular to endangered patients with metabolic alterations such as compensatory hyperinsulinemia, impaired fasting glucose, impaired glucose tolerance, and diabetes, who have an impaired EPC number and function, and this could be a further challenge to future investigations $[14,18]$.

However, available data suggest that metabolic interventions by either lifestyle change, better glucose and lipid control, or certain other agents are able to improve EPC number and function [17].

This review will focus on the role of EPC in vascular repair and available therapeutic options in diabetic patients.

\section{Endothelium Biology}

Despite being originally considered to be just a simple mechanic barrier between the blood and vascular wall, the endothelium is now recognized as the most important component of healthy vascular function. It maintains the anticoagulant, antiplatelet, and fibrinolytic properties of vascular cells. The healthy endothelium in response to physical and chemical signals produces a wide range of factors that regulate vascular tone, cellular adhesion, thromboresistance, smooth muscle cell proliferation, and vessel wall inflammation. In few words, the endothelium is regarded as a very complex endocrine and paracrine organ $[19,20]$.

Effects on the vascular tone were the first discovery unveiling the importance of the endothelium. The endothelium produces several vasoactive molecules that relax or constrict the vessels, interplaying with circulating vasoactive mediators like bradykinin or thrombin. This vasomotion is of crucial importance for tissue oxygen supply and metabolic demand and is also involved in remodeling of vascular structures and regulating long-term organ perfusion. Maintaining the functional integrity of the endothelium, therefore, is critical for the preservation of blood flow and the prevention of thrombosis [21,22].

Nitric oxide (NO) is the most important mediator released by endothelial cells, historically named and originally identified as endothelium-derived relaxing factor. NO is produced from L-arginine by the action of endothelial NO synthase (eNOS) in the presence of several cofactors. This gas activates guanylate cyclase in vascular smooth muscle cells, leading to cGMP-mediated vasodilatation. In addition, this enzyme may be activated under certain circumstances by other signaling molecules like bradykinin, adenosine, vascular endothelial growth factor (during hypoxia), and serotonin (during platelet aggregation) [23, 24].

The endothelium also mediates vasodilatation through other mechanisms, like the endothelium-derived hyperpolarizing factor via accumulation of potassium ions in the intercellular space and/or due to tissue electrical conductivity, allowing propagation of electrical signals along the axis of blood vessels by means of homocellular gap junctions and throughout the vascular wall itself by means of myoendothelial gap junctions $[25,26]$.

In normal vascular physiology, NO plays a key role in preserving the vessel wall in a quiescent state by inhibition of inflammation, thrombosis, and cellular proliferation through limiting oxidative phosphorylation in mitochondria and snitrosylation of cysteine residues in a wide range of proteins, including transcription factors like $\mathrm{NF} \kappa \mathrm{B}$, cell cyclecontrolling proteins, and proteins involved in generation of tissue factors $[22,27]$.

Another endothelium-derived vasodilator that acts independently of NO is prostacyclin, derived by the action of the cyclooxygenase system. Prostacyclin is an eicosanoid which chiefly prevents formation of the platelet plug involved in primary hemostasis. In humans, it appears to have a more limited role in the maintenance of vasodilator tone, although it may contribute to some of the other regulatory roles of the endothelium $[22,26]$.

Other substances important for vasomotion are constrictors like endothelin and vasoconstrictor prostanoids generated in the endothelium, as well as angiotensin I converted to angiotensin II at the endothelial surface. These vasoconstrictor agents predominantly act locally but may also exert some systemic effects and have a role in the regulation of arterial structure and remodeling. Because of these properties, vasoconstrictor substances are believed to be involved in the pathogenesis of vascular diseases of several organ systems, including the heart, general circulation, and brain $[22,28,29]$.

\section{Diabetes, Endothelial Injury, and Dysfunction}

Chronic hyperglycemia leads to vascular disease, and multiple studies in patients and animal models and in vitro have revealed that hyperglycemia alters endothelial metabolism and function, causing vascular injury. Vascular injury contributes to all diabetic complications, whether micro- or macrovascular, in all forms of diabetes mellitus. Prolonged and/or repeated exposure to other cardiovascular risk factors can additionally seriously damage the endogenous protective mechanisms within endothelial cells. As a consequence, the endothelium may become dysfunctional, and lose is vasomotor properties [30, 31].

An important biochemical abnormality accompanying diabetes mellitus and also important for vascular injury is the formation of advanced glycation end products (AGEs). Driven by hyperglycemia and oxidant stress, the effects of AGEs on vessel wall homeostasis may account for the rapidly progressive atherosclerosis associated with diabetes [32, 33].

Although the mechanisms underlying this phenomenon are probably multifactorial, the role of the diacylglycerolprotein kinase $\mathrm{C}(\mathrm{PKC})$ pathway has recentyl been recognized as very important in in-vivo and in-vitro studies. PKC may have several adverse effects on endothelial function, such as activation of superoxide-producing enzymes like the nicotinamide adenine dinucleotide phosphate (NADPH) oxidase, and increased expression of a dysfunctional, superoxideproducing, uncoupled endothelial nitric oxide synthase (NOS III). PKC-mediated superoxide production may inactivate NO derived from endothelial NOS III and may inhibit the activity and/or expression of the NO downstream target, 
the soluble guanylyl cyclase, resulting in impaired vasomotion properties of the endothelium. Furthermore, within the vessel wall, collagen-linked AGEs may "trap" plasma proteins, interact with specific receptors, and modulate a large number of cellular properties. On plasma low density lipoproteins (LDL), AGEs initiate oxidative reactions that promote the formation of oxidized LDL [32-35].

However, in patients with diabetes, endothelial dysfunction is a coherent finding. There is a general consensus that hyperglycemia and diabetes lead to impaired $\mathrm{NO}$ production and damaged vasodilatatory activity $[33,35]$.

Even more importantly, endothelial cells exposed to chronic hyperglycemia can also lose integrity, progress to senescence, and undergo apoptosis $[36,37]$.

The outcome of this detrimental process is detachment of endothelial cells, which are released into the circulation. In the bloodstream they can be detected as circulating mature endothelial cells or as their apoptotic microparticles, if endothelial cells did not detach as entire cells [38].

McClung et al. have shown that circulating mature endothelial cell levels are higher in type 2 diabetic patients, irrespective of glucose control represented by $\mathrm{HbA}_{1 \mathrm{c}}$ levels. Elevated endothelial cell-derived endothelial microparticle levels are predictive of the presence of coronary heart disease, and it is an even more significant independent risk factor than presence of diabetes, lipid levels, or hypertension [38-40].

The result of this apoptotic process is arterial denudation, which triggers a cascade of proatherosclerotic processes like platelet adhesion and aggregation, inflammation, smooth muscle cell proliferation, migration, and matrix secretion $[38,41]$.

\section{Endothelial Repair}

As already mentioned, structural or functional damage of the endothelium is a result of cumulative exposure to cardiovascular risk factors. These factors have the ability to induce biochemical cellular toxicity and/or promote endothelial cell loss by apoptosis.

The resulting extent of endothelial dysfunction depends not only on the extent of injury, but also on the biologic capacity for repair. For this reason, endothelial reparatory mechanisms are crucial in reestablishing vessel integrity.

Two mechanisms involved in this process have been recently identified.

The endothelium itself has a relatively weak capacity for self-repair, because it is built from mostly terminally differentiated cells with low proliferative capacity. However, mature endothelial cells surrounding the injured locus in the endothelium can replicate in situ and replace lost and damaged cells $[38,42]$.

Recently, it has become evident that some forms of cells, recruited from the bone marrow and from some other tissues, circulate in the peripheral blood and have the ability to be embedded in the injured endothelium and differentiate into mature cells with endothelial characteristics. These cells were called EPCs, and they seemed to be an important mechanism for maintenance and repair of the endothelium.
Several studies have shown that EPCs may be derived from different sources such as the bone marrow and nonbone marrow organs like the spleen. EPCs are a heterogeneous group of cells presenting in different stages of differentiation in the blood stream. There are at least two different known subtypes of EPCs: the early and late EPCs. Early EPCs occur as colony forming units (CFU) and have some endothelial characteristics, like harboring markers of CD31, TIE2, and VEGFR2. Late EPCs, or outgrowth EPCs, have different growth patterns. Outgrowth EPCs express additional endothelial characteristics, such as VE-cadherin and von Willebrand factor, in addition to CD31, CD133, CD34, and VEGFR2 [4]. These outgrowth EPCs will further differentiate into mature endothelial cells for angiogenesis and vasculogenesis [14, 38, 43]. The ability of EPCs for functional vascular repair varies with the maturation state of the cell $[14,38]$.

There are some difficulties in precise characterization of EPCs, because some of these cell surface markers are shared with other cell types like hematopoietic stem cells and mature endothelial cells. Currently, EPCs are defined as cells positive for both a hematopoietic stem cell marker such as CD34 and an endothelial marker protein such as VEGFR2 [14, 38, 44].

Mobilization of these cells into the circulation is in a certain magnitude NO-dependent and may be impaired in patients with present cardiovascular risk factors, like diabetes and smoking [45]. There are also several factors responsible for mobilizing EPCs from the bone marrow or other organs into the blood stream, like growth factors and cytokines, including VEGF (vascular endothelial growth factor), SDF-1 $\alpha$ (stromal-cell-derived factor- $1 \alpha$ ), erythropoietin, and estrogens. Interestingly, the number of EPCs seems to be inversely correlated with the severity and degree of atherosclerosis $[46,47]$.

EPCs migrate toward injured endothelial regions, after they have been mobilized into the circulation. At these places they home or adhere and start to proliferate beginning vascular repair. An important factor in directing circulating progenitor cells to sites of vascular injury is chemokine signaling, like tissue hypoxia induced upregulation of SDF- $1 \alpha$ in ischemic tissues. Homing to the injured sites is facilitated through interactions between SDF- $1 \alpha$ and CXCR4 (CXC chemokine receptor 4) [48-50].

Once embedded in the injured site, EPCs are involved in endothelial repair either by proliferation and forming new endothelial cells or by releasing provasculogenic cytokines and growth factors important for the proliferation of local mature endothelial cells or other EPCs [48].

Recent evidence has suggested that cardiovascular risk factors interfere not only with the differentiation and function of endothelial progenitor cells, but also with the recruitment of these cells $[14,38,39,44,45]$.

However, blood flow in ischemic tissues could be enhanced by the increase in the number of endothelial circulating progenitor cells, augmented whether by cell transfusion or induced mobilization, involving mechanisms like enhanced restoration and integrity of the endothelial lining, and neointimal formation $[46,51,52]$. 


\section{Endothelial Repair in Diabetic Patients}

Diabetes, hypercholesterolemia, hypertension, and smoking, leading to atherosclerosis, and several other forms of vascular disease are associated with a reduced number and impaired functional activity of circulating EPCs [14, 18, 31, 32, 38].

Apparently, there is a glucometabolic continuum in EPC biology. In particular, all forms of glucose disorders are associated with abnormalities in EPC biology, including impaired fasting glucose and impaired glucose tolerance [47].

Individuals with disorders of glucose metabolism have reduced levels of circulating EPCs. Damaged mobilization, decreased proliferation, and shortened survival in the circulation may contribute to a reduced number of circulating EPCs in diabetic patients. Several mechanisms could be responsible for defects in EPC mobilization, migration and homing of EPC in diabetic patients, including decreased NO bioavailability, defects in intracellular signaling, inflammation and adipokines, reactive oxygen species, and direct effects of insulin and IGF-1 $[38,53,54]$.

NO bioavailability and PI3K/Akt signaling are crucial in EPC mobilization from bone marrow. In insulin resistant states both mechanism are damaged $[53,55]$.

A consistent finding in insulin resistant humans and animals with impaired EPC mobilization and function in experimental models is decreased NO bioavailability. NO is important for the normal function of EPCs after mobilization. A substantial requirement for NO in migration, homing, and neovascularization was shown in in vitro and in vivo studies $[53,55,56]$.

Another important mechanism damaged in insulin resistant humans and animals is the PI3K/Akt pathway. This pathway mediates metabolic effects like insulin-stimulated glucose uptake in metabolically active tissues and insulin- or shear-stress induced NO production in endothelial cells. In EPCs, inhibition of this pathway abolishes their mobilization in response to several stimuli [47].

After mobilization, there are more issues limiting the regenerative ability of EPCs in diabetes.

The capacity for effective homing to the injured blood vessel, adhesion and integration into the endothelium, proliferation, and differentiation is crucial for EPCs to promote vascular repair. EPCs from diabetic animals and humans show impaired response to chemotactic stimuli, reduced proliferative potential, and diminished ability to form vascular-like structures in vitro. Hyperglycemia is associated with reduced expression of SDF- $1 \alpha$, a chemokine occurring in injured tissues, and decreased expression of CXCR4 in peripheral mononuclear cells and EPCs. Both may inhibit homing of EPCs from the circulation to the injured endothelium, since adhesion of EPCs to sites of vascular injury is dependent on an interaction between locally produced chemokines and the CXCR4 receptor $[48,49]$.

Damaged PI3K/Akt signalling has been implicated to impair EPC differentiation and inhibition of EPC apoptosis, like in inflammatory states [57]. Systemic inflammation is known to contribute to atherosclerotic vascular disease by stimulation of proatherogenic adhesion molecules in mature endothelial cells, but it affects also EPC-mediated vascular regeneration. Inflammatory factors impair EPC survival, differentiation, and function. On the contrary, inflammatory mediators released from the injured endothelium stimulate the production of growth factors and cytokines necessary to facilitate EPC release and homing. It is likely that persistent inflammation (even a low level inflammation) has harmful effects, but transient inflammatory response following endothelial injury is associated with EPC mobilization and may be beneficial $[47,58]$.

Adipocytes are another factor involved in damaged vascular repair in diabetic patients. These metabolic active cells produce several cytokines and contribute to a chronic inflammatory state by secreting the proinflammatory cytokine TNF- $\alpha$ which reduces the proliferation of EPCs [59].

Leptin, another adipokine, increased in vitro tubule formation in EPC cultures, but at higher concentration EPC migration was inhibited. Leptin was also shown to be able to enhance the capacity of EPC to adhere to matured endothelial cells or the extracellular matrix by increasing the expression of specific integrins. These effects led to enhanced reendothelialization when leptin-stimulated human EPCs were given to mice. However, obese insulin resistant humans have increased circulating leptin concentrations and impaired leptin effects and have been assumed to suffer from "leptin resistance" $[60,61]$.

Reactive oxygen species (ROS) produced in diabetic patients also contribute to endothelial injury and impair endothelial repair. ROS are directly cytotoxic for endothelial cells, react with NO, decrease NO bioavailability, and form peroxynitrite anions which act as powerful oxidants. Although it seems that EPCs from healthy individuals are relatively resistant to oxidant stress, in diabetic patients ROS may lead to EPC impairment. Mechanisms may include increased ROS production and impaired endogenous antioxidant defence $[62,63]$.

Among other substances, insulin and IGF-1 influence the mobilization and differentiation of EPCs. In a small study of patients with poorly controlled type 2 diabetes, insulin therapy led to an increase in circulating EPCs. Insulin-mediated EPC mobilization was significantly dependent on SDF-1 polymorphism; mobilization was significantly enhanced in subjects with the SDF-1 $3^{\prime}-\mathrm{A} / \mathrm{G}$ allele. Insulin stimulates the clonogenic and angiogenic potential of EPCs; the effect is more likely mediated through the IGF-1 receptor than the insulin receptor itself. Humpert and coworkers have demonstrated that insulin stimulates the outgrowth in vitro of EPCs from patients with type 2 diabetes. This effect was completely abrogated by IGF-1 receptor blockade but unaltered after blocking the insulin receptor itself. The IGF-1 receptor-dependent effect of insulin on EPC growth was largely mediated by the MAPKs ERK1/2 (extracellular-signalregulated kinase) and p38 $[64,65]$.

\section{Current Available Therapeutic Options}

New concepts of endothelial injury and repair have offered exciting perspectives for new researches in preventing and/or treating cardiovascular disease. Despite the fact that EPCs are recently discovered, lifestyle interventions and several 
drugs successfully used for treatment of diabetes and/or cardiovascular diseases have proven beneficial effects to EPC biology.

Many of those lifestyle and pharmacological interventions already have established favourably cardiovascular benefits $[14,17]$.

Exercise as a lifestyle modification has a potential to increase the number of endothelial progenitor cells and improve their migratory capacity, helping to repair the damaged endothelium [66-68]. In healthy volunteers, exercise increased the number of EPCs in the circulation [69]. In patients with stable coronary artery disease, an increased number of circulating EPCs and reduced EPC apoptosis were found after 28 days of moderate exercise training [70].

Vascular repair could be enhanced also with nutrition. There is some evidence for favourable effects of polyunsaturated fatty acids from different sources on vascular biology [71-73]. A hypocaloric Mediterranean diet has also been proved as enhancing endothelial repair [74, 75].

Considering current available medical treatment for diabetes and its comorbidities, there are several established classes of drugs with beneficial effects on endothelial repair.

Among these drugs are statins, angiotensin-converting enzyme inhibitors, angiotensin II type 1 receptor blockers, some sulphonylureas like gliclazide, metformin, PPARgamma agonists, GLP-1, DPP-4 inhibitors, and insulin, which are able to increase the number and/or functional activity of EPCs, affecting different mechanisms, as some experimental and clinical studies have suggested.

Statins are widely used among diabetic and nondiabetic patients as antilipemic drugs, with a profound effect on the incidence of cardiovascular events and mortality. They may also modulate vascular repair through increasing EPC numbers and inducing EPC differentiation by activation of the PI3K pathway and stimulation of NO production, in addition to their primary effects on lipoprotein metabolism $[57,76]$.

In general, the effect of statins on EPC count was a significant increase occurring shortly after treatment initiation. It seems that it could be a class effect of all statins, since there are many of them studied with similar results, including simvastatin, atorvastatin, pravastatin, and rosuvastatin. Some secondary outcomes like left ventricular (LV) volume, ejection fraction (EF), and flow mediated dilation (FMD) could also be improved in some studies. Furthermore, even herbal products containing lovastatin have the capacity to improve EPC counts. Only one study showed a negative correlation between statin therapy and EPC count, but this study was cross-sectional, on a group of patients receiving various statins. It is still unclear whether the effect of statins is dose dependent, and larger randomized trials are necessary for firmer proof.

An overview of clinical data involving statins treatment and their effects on EPCs is shown in Table 1.

Similarly, beneficial outcomes on EPC biology were found for some antihypertensive drugs with favourable metabolic effects, like ACEIs (angiotensin-converting enzyme inhibitors) and ARBs (angiotensin II type 1 receptor blockers). For both classes of drugs cardiovascular benefits are well established, beyond their antihypertensive effect [94]. It was shown that ACEi and ARB treatment increased numbers and function of EPCs in patients with a variety of cardiovascular diseases, including arterial hypertension, stable coronary artery disease, and acute coronary syndromes. Treatment with these classes of antihypertensive drugs could contribute to their cardioprotective effect in type 2 diabetes, even independent of their action on blood pressure [95] like in a study where both olmesartan and irbesartan increased the numbers of EPCs in a group of patients with type 2 diabetes.

Calcium channel blockers (CCBs) decrease blood pressure by inhibiting L-type voltage-gated calcium channels, leading to a decreased level of intracellular calcium. They act on vascular smooth muscle, inducing vasodilation followed by decreased blood pressure. Preliminary results from two studies reported affirmative outcomes on EPC numbers and function with CCBs in patients with essential hypertension $[96,97]$.

In addition to data on EPC, in some trials there are also data about improved flow mediated vessel dilatation, markers of inflammation, and in one trial there are also favorable mortality data. Most trials presented affirmative results in regard to EPCs count and/or function, with few exceptions. However, larger trials are needed to get more reliable data.

A summary of currently available clinical data on antihypertensives and their effect on EPC biology is shown in Table 2.

Several classes of agents used for treatment of diabetes are also shown to enhance EPC biology. Among them is metformin, commonly used as first-line treatment in patients with type 2 diabetes and as supplementary treatment in patients with type 1 diabetes. It has also established vasculoprotective effects. These effects could be at least in part explained by increased circulating EPCs after initiating treatment with metformin $[107,108]$. The effect was even augmented with addition of gliclazide [108]. Otherwise, positive effects of gliclazide as monotherapy could be also proven; it improved also flow mediated vessel dilatation and some markers of oxidative stress [109].

A further class of antidiabetic medications found to have beneficial effects on vascular repair are thiazolidinediones. Thiazolidinediones are peroxisome proliferator-activated receptors (PPAR) $\gamma$ agonists and are in clinical use for glucoregulation, but these insulin-sensitizing drugs could also improve some other cardiovascular risk factors. At the time, pioglitazone and rosiglitazone are approved for use by the FDA. Considering EPC biology, rosiglitazone was able to normalize impaired EPC migratory activity and to increase EPC numbers in culture [117]. In patients with type 2 diabetes rosiglitazone was effective in reducing NADPH oxidase activity and thus improving the reendothelialization by EPCs [63]. Pioglitazone was also shown to increase the number and function of EPCs and to decrease EPC apoptosis in animal models [118]. Human studies with pioglitazone were also mainly affirmative [110-113].

Other mechanisms in glucose control affect glucagon like peptide 1 (GLP-1) and its analogues and inhibitors of degradation. 
TABLE 1

\begin{tabular}{|c|c|c|c|c|}
\hline Reference & Study drug & Study population and design & $\begin{array}{l}\text { Study } \\
\text { duration }\end{array}$ & Findings \\
\hline Vasa et al. [77] & $\begin{array}{l}\text { Atorvastatin } \\
40 \mathrm{mg} / \text { day }\end{array}$ & $\begin{array}{l}15 \text { patients with coronary } \\
\text { artery disease, no control } \\
\text { group }\end{array}$ & 4 weeks & $\begin{array}{l}1.5 \text {-fold } \uparrow \text { in EPC count after } 1 \\
\text { week } \\
3 \text {-fold } \uparrow \text { in EPC count after } 4 \\
\text { weeks } \\
\uparrow \text { EPC functional activity }\end{array}$ \\
\hline del Papa et al. [78] & $\begin{array}{l}\text { Simvastatin } \\
20 \mathrm{mg} / \text { day }\end{array}$ & $\begin{array}{l}40 \text { patients } \\
(20 \text { hypercholesterolemic } \\
\text { versus } \\
20 \text { normocholesterolemic } \\
\text { patients with systemic } \\
\text { sclerosis) }\end{array}$ & 4 weeks & $\begin{array}{l}\text { Simvastatin } \uparrow \text { EPC count in } \\
\text { patients without systemic sclerosis } \\
\text { In patients with systemic sclerosis } \\
\text { there was an attenuated response, } \\
\text { mainly in patients with late disease }\end{array}$ \\
\hline Westerweel et al. [79] & $\begin{array}{l}\text { Simvastatin } \\
80 \mathrm{mg} / \text { day versus } \\
\text { simvastatin } \\
10 \mathrm{mg} / \text { ezetimibe } \\
10 \mathrm{mg} / \text { day }\end{array}$ & $\begin{array}{l}20 \text { obese patients with } \\
\text { metabolic syndrome, } \\
\text { randomized trial, crossover } \\
\text { design }\end{array}$ & $6+6$ weeks & $\uparrow$ EPC counts in both groups \\
\hline Pesaro et al. [80] & $\begin{array}{c}\text { Simvastatin } \\
80 \mathrm{mg} / \text { day versus } \\
\text { simvastatin } \\
20 \mathrm{mg} / \text { ezetimibe } \\
10 \mathrm{mg} / \text { day }\end{array}$ & $\begin{array}{l}68 \text { patients with LDL levels } \\
>70 \mathrm{mg} / \mathrm{dL} \text { pretreated with } \\
\text { simvastatin } 20 \mathrm{mg} \text {, } \\
\text { randomized trial }\end{array}$ & 6 weeks & $\begin{array}{l}\text { No effect on EPC count in either } \\
\text { group } \\
\text { Similar reduction in LDL levels in } \\
\text { both groups }\end{array}$ \\
\hline Hibbert et al. [81] & $\begin{array}{l}\text { Atorvastatin } \\
80 \mathrm{mg} / \text { day versus no } \\
\text { statin }\end{array}$ & $\begin{array}{l}20 \text { male patients undergoing } \\
\text { angiography for stent } \\
\text { placement randomized to } \\
\text { atorvastatin or no statin } \\
\text { treatment }\end{array}$ & 4 days & $\begin{array}{l}3.5 \text {-fold } \uparrow \text { in EPC count in the } \\
\text { statin group }\end{array}$ \\
\hline Baran et al. [82] & $\begin{array}{c}\text { Atorvastatin } \\
40 \mathrm{mg} / \text { day versus } \\
\text { placebo }\end{array}$ & $\begin{array}{l}60 \text { patients undergoing } \\
\text { first-time CABG, placebo } \\
\text { controlled, randomized } \\
\text { double-blind study }\end{array}$ & 14 days & $\begin{array}{l}\uparrow \text { EPC count in atorvastatin group } \\
\downarrow \text { incidence of postoperative atrial } \\
\text { fibrillation in the statin group }\end{array}$ \\
\hline Sobrino et al. [83] & $\begin{array}{l}\text { Atorvastatin } \\
20 \mathrm{mg} / \text { day }\end{array}$ & $\begin{array}{l}48 \text { patients with first ever } \\
\text { nonlacunar ischaemic Stroke } \\
16 \text { patients receiving } \\
\text { atorvastatin during the first } 4 \\
\text { days }\end{array}$ & 7 days & $\begin{array}{l}\uparrow E P C \text { count in atorvastatin group } \\
\text { Effect probably due to NO related } \\
\text { mechanisms }\end{array}$ \\
\hline Huang et al. [84] & $\begin{array}{l}\text { Atorvastatin } \\
40 \mathrm{mg} / \text { day versus } \\
\text { atorvastatin } \\
10 \mathrm{mg} / \text { day }\end{array}$ & $\begin{array}{l}100 \text { patients with ischemic } \\
\text { cardiomyopathy randomized } \\
\text { to } 10 \mathrm{mg} \text { or } 40 \mathrm{mg} \text { of } \\
\text { atorvastatin } \\
\text { Control group: } 100 \text { healthy } \\
\text { volunteers }\end{array}$ & 1 year & $\begin{array}{l}40 \mathrm{mg} \text { of atorvastatin had a more } \\
\text { profound } \uparrow \text { in EPC count } \\
\text { Higher dose of atorvastatin was } \\
\text { associated with a more marked } \downarrow \\
\text { in total and LDL cholesterol, } \\
\text { hsCRP, oxLDL, and circulating } \\
\text { endothelial microparticles }\end{array}$ \\
\hline Spadaccio et al. [85] & $\begin{array}{c}\text { Atorvastatin } \\
20 \mathrm{mg} / \text { day versus } \\
\text { placebo }\end{array}$ & $\begin{array}{l}50 \text { patients undergoing } \\
\text { elective coronary surgery, } \\
\text { randomized crossover trial }\end{array}$ & 3 weeks & $\begin{array}{l}\uparrow \text { EPC count in atorvastatin group } \\
\text { SDF- } 1 \alpha \text {, CSF, and VEGF } \\
\text { unaffected }\end{array}$ \\
\hline Leone et al. [86] & $\begin{array}{c}\text { Atorvastatin } \\
80 \mathrm{mg} / \text { day } \\
\text { immediately versus } \\
20 \mathrm{mg} / \text { day } \\
\text { atorvastatin after } \\
\text { hospital discharge }\end{array}$ & $\begin{array}{l}40 \text { patients with AMI } \\
\text { undergoing PCI, randomized } \\
\text { trial }\end{array}$ & 4 months & $\begin{array}{l}\text { Larger dose of atorvastatin related } \\
\text { to larger } \uparrow \mathrm{EPC} \text { count } \\
\mathrm{LV} \text { volume, EF, and wall motion } \\
\text { were similar in both groups after } \\
\text { study completion }\end{array}$ \\
\hline Lu et al. [87] & $\begin{array}{l}\text { Pravastatin versus } \\
\text { placebo versus } \\
\text { Xuezhikang }\end{array}$ & $\begin{array}{l}88 \text { patients with essential } \\
\text { hypertension, randomized } \\
\text { trial }\end{array}$ & 8 weeks & $\begin{array}{l}\uparrow \text { EPC count and proliferative } \\
\text { ability in pravastatin and } \\
\text { Xuezhikang (contains lovastatin) } \\
\text { group }\end{array}$ \\
\hline
\end{tabular}


TABle 1: Continued.

\begin{tabular}{|c|c|c|c|c|}
\hline Reference & Study drug & Study population and design & $\begin{array}{l}\text { Study } \\
\text { duration }\end{array}$ & Findings \\
\hline Paradisi et al. [88] & Pravastatin $40 \mathrm{mg} /$ day & $\begin{array}{l}20 \text { patients, healthy } \\
\text { postmenopausal women, } \\
\text { randomized, double-blind } \\
\text { trial }\end{array}$ & 8 weeks & $\begin{array}{l}\uparrow \text { EPC colony forming units } \\
\downarrow \text { count of senescent cells }\end{array}$ \\
\hline Tousoulis et al. [89] & $\begin{array}{l}\text { Rosuvastatin } \\
10 \mathrm{mg} / \text { day }\end{array}$ & $\begin{array}{l}60 \text { patients with systolic heart } \\
\text { failure, randomized trial }\end{array}$ & 1 month & $\begin{array}{l}\uparrow \text { EPC count improved } \\
\text { No change in inflammatory and } \\
\text { oxidative markers }\end{array}$ \\
\hline Erbs et al. [90] & $\begin{array}{c}\text { Rosuvastatin } \\
40 \text { mg/day versus } \\
\text { placebo }\end{array}$ & $\begin{array}{l}42 \text { patients with chronic heart } \\
\text { failure, randomized trial }\end{array}$ & 12 weeks & $\begin{array}{l}\uparrow \text { EPC count } \\
\uparrow \text { homing of EPC } \\
\uparrow \text { FMD, } \uparrow \text { VEGF }\end{array}$ \\
\hline Yoshida et al. [91] & $\begin{array}{l}\text { Pitavastatin } 2 \mathrm{mg} / \text { day } \\
\text { versus placebo }\end{array}$ & $\begin{array}{l}30 \text { male smokers, randomized } \\
\text { trial }\end{array}$ & 4 weeks & $\begin{array}{l}\text { No effect on EPC count } \\
\uparrow \text { FMD, } \downarrow \text { markers of oxidative } \\
\text { stress in pitavastatin group }\end{array}$ \\
\hline Spiel et al. [92] & $\begin{array}{l}\text { Simvastatin } \\
80 \mathrm{mg} / \text { day versus } \\
\text { rosuvastatin } \\
10 \mathrm{mg} / \text { day versus } \\
\text { placebo }\end{array}$ & $\begin{array}{l}6 \text { healthy volunteers, } \\
\text { randomized, double-blind, } \\
\text { placebo controlled, crossover } \\
\text { study }\end{array}$ & 5 days & $\begin{array}{l}3 \text {-fold } \uparrow \text { EPC count in statin } \\
\text { groups } \\
\text { Class effect? }\end{array}$ \\
\hline Hristov et al. [93] & $\begin{array}{c}\text { Low dose of statins } \\
\text { (10/20 mg/day) versus } \\
\text { high dose } \\
\text { (40 mg/day) versus } \\
\text { untreated }\end{array}$ & $\begin{array}{l}209 \text { CAD patients } \\
\text { (without statin: } 65 \text {, low dose } \\
\text { statin: } 101 \text {, and higher dose } \\
\text { statin: } 43 \text { patients) } \\
\text { cross-sectional study }\end{array}$ & None & $\begin{array}{l}40 \mathrm{mg} / \mathrm{d} \text { of statin treatment has } \\
\text { significantly } \downarrow \text { EPC count } \\
\text { Lower doses had no impact on } \\
\text { EPC count } \\
\text { Continuous statin therapy } \\
\text { inversely correlated with EPC } \\
\text { numbers }\end{array}$ \\
\hline
\end{tabular}

GLP-1 is a hormone, released from enteroendocrine cells in the intestine, and has been shown to exert cardiovascular protective effects. Results indicated that GLP-1 improves VEGF generation, which contributed to improvement of EPCs biological function. VEGF is a necessary mediator of the effects of GLP-1 on EPCs [119]. Interestingly, there are no data about GLP injectables and EPCs number and function in diabetic patients.

Dipeptidyl peptidase 4 (DPP 4) inhibitors are a recently introduced class of oral hypoglycemic agents. There is one study that showed an increase in EPC number in patients treated with sitagliptin after 4 weeks of treatment in comparison to metformin. In addition, plasma stromal-derived factor- $1 \alpha$ (SDF- $1 \alpha)$ levels also increased in sitagliptin treated patients, leading to enhanced EPC release from bone marrow [114]. In another study sitagliptin improved both SDF- $1 \alpha$ levels and flow mediated dilatation. In this study voglibose was used as active comparator but with no effect on EPC biology despite its positive effect on blood vessels dilation [115].

In subjects with type 1 diabetes and in patients with type 2 diabetes who fail to respond adequately to oral therapies, insulin is used to achieve glycaemic control. Although there is some evidence that short-term insulin treatment and tight blood glucose control decrease adverse cardiovascular events after myocardial infarction, studies have failed to show superiority of insulin in comparison to other drugs used for glucose control on the long term [120]. However, as discussed previously, insulin and certain insulin analogues have been shown to mobilize EPCs and improve EPC parameters in vitro [47]. In patients with type 2 diabetes mellitus, long acting insulin analogues glargine and detemir were able to raise the EPC count, with no significant difference between both drugs. Differences were noticed in the number of hypoglycemic events and weight gain, in favour of insulin detemir [116].

Studies on effects of antidiabetic treatment on EPCs are listed in Table 3.

Some other hormones occasionally used in the treatment of specific subgroups of diabetic patient may also improve vascular repair, like estrogens and erythropoietin.

Estrogens are shown to be effective in mobilizing EPCs and reducing neointima formation after arterial injury in animals [121]. These effects are NOS-mediated and depend on FGF-2 (fibroblast growth factor-2) activity. Furthermore, in healthy fertile women, EPCs are mobilized cyclically in response to raising estrogens during the menstrual cycle, providing an interesting explanation for gender differences in cardiovascular risk $[47,122]$.

Erythropoietin, a kidney hormone that controls erythropoiesis, was also expected to be beneficial in improving vascular repair in humans but without definitive proof yet. In a trial on patients with ST-elevation acute myocardial infarction there was only a nonsignificant improvement in EPC count after a single dose of erythropoietin in the acute phase, with no impact on infarct size [123]. 
TABLE 2

\begin{tabular}{|c|c|c|c|c|}
\hline Reference & Study drugs & Study population and design & $\begin{array}{l}\text { Study } \\
\text { duration }\end{array}$ & Findings \\
\hline Cacciatore et al. [98] & $\begin{array}{l}\text { Enalapril } 20 \mathrm{mg} / \text { day } \\
\text { versus zofenopril } \\
30 \mathrm{mg} / \text { day, }\end{array}$ & $\begin{array}{l}36 \text { patients with newly diagnosed } \\
\text { mild hypertension, randomized trial }\end{array}$ & 5 years & $\begin{array}{l}\uparrow \text { EPC count } \\
\text { No difference between groups } \\
\downarrow \text { intima media thickness }\end{array}$ \\
\hline Sun et al. [99] & $\begin{array}{l}\text { Perindopril } 4 \mathrm{mg} / \mathrm{day} \\
\text { versus placebo }\end{array}$ & $\begin{array}{l}68 \text { patients with acute myocardial } \\
\text { infarction and T2DM }\end{array}$ & $\begin{array}{l}28 \text { days after } \\
\text { PCI }\end{array}$ & $\begin{array}{l}\uparrow \text { EPC count } \\
\uparrow \text { VEGF } \\
\uparrow \text { SDF- } 1 \alpha \\
\uparrow \text { LVF } \\
\downarrow C V \text { mortality in the perindopril } \\
\text { group }\end{array}$ \\
\hline Min et al. [100] & Ramipril 5 mg/day & $\begin{array}{l}36 \text { nondiabetic patients with acute } \\
\text { myocardial infarction }\end{array}$ & 4 weeks & $\begin{array}{l}\uparrow \text { EPC count } 1.5 \text {-fold after } 1 \text { week, } \\
2.5 \text {-fold after } 4 \text { weeks } \\
\uparrow \text { EPC proliferation, migration, and } \\
\text { adhesion }\end{array}$ \\
\hline Cangiano et al. [101] & $\begin{array}{l}\text { Perindopril } 10 \mathrm{mg} / \text { day } \\
\text { versus valsartan } \\
320 \mathrm{~m} / \text { day }\end{array}$ & $\begin{array}{l}\text { Patients with acute coronary } \\
\text { syndromes } \\
16 \text { receiving perindopril } \\
17 \text { receiving valsartan } \\
20 \text { healthy controls }\end{array}$ & 30 days & $\begin{array}{l}\uparrow \text { EPC mobilization, } \uparrow \text { VEGF in the } \\
\text { perindopril group } \\
\text { No effects found for valsartan }\end{array}$ \\
\hline Porto et al. [102] & $\begin{array}{c}\text { Ramipril } 5 \mathrm{mg} / \text { day } \\
\text { versus telmisartan } \\
80 \mathrm{mg} / \text { day }\end{array}$ & $\begin{array}{l}42 \text { patients with acute coronary } \\
\text { syndrome, randomized trial }\end{array}$ & $\begin{array}{l}20 \text { days after } \\
\text { PCI }\end{array}$ & $\begin{array}{l}\uparrow E P C \text { count in both groups } \\
\text { Telmisartan had a more profound } \\
\text { anti-inflammatory effect }\end{array}$ \\
\hline Pelliccia et al. [103] & $\begin{array}{c}\text { Telmisartan } 40 \mathrm{mg} / \text { day } \\
\text { versus placebo }\end{array}$ & $\begin{array}{l}40 \text { normotensive patients with } \\
\text { CAD, randomized trial }\end{array}$ & 4 weeks & $\begin{array}{l}\uparrow \mathrm{EPC} \text { count } \\
\uparrow \mathrm{FMD}\end{array}$ \\
\hline Bahlmann et al. [95] & $\begin{array}{l}\text { Olmesartan } 40 \mathrm{mg} / \text { day } \\
\text { versus placebo, } \\
\text { double-blind RCT } \\
\text { Irbesartan } 300 \mathrm{mg} / \text { day, } \\
\text { open trial }\end{array}$ & $\begin{array}{l}18 \text { patients with T2DM randomized } \\
\text { to olmesartan or placebo } \\
20 \text { patients with T2DM receiving } \\
\text { irbesartan }\end{array}$ & 12 weeks & $\begin{array}{l}\uparrow \mathrm{EPC} \text { count with both olmesartan } \\
\text { and irbesartan }\end{array}$ \\
\hline Tan et al. [104] & Losartan $100 \mathrm{mg} /$ day & & & $\begin{array}{l}\uparrow \mathrm{EPC} \text { count } \\
\uparrow \mathrm{FMD}\end{array}$ \\
\hline Suzuki et al. [105] & $\begin{array}{l}\text { Losartan } 50 \mathrm{mg} / \text { day } \\
\text { versus } \\
\text { trichlormethiazide } \\
4 \mathrm{mg} / \text { day }\end{array}$ & $\begin{array}{l}36 \text { patients with hypertension } \\
\text { randomized to losartan or } \\
\text { trichlormethiazide } \\
\text { Control group: } 18 \text { normotensive } \\
\text { patients }\end{array}$ & 4 weeks & $\begin{array}{l}\uparrow \text { EPC count with losartan } \\
\text { Hypertensive patients had a lower } \\
\text { EPC count in comparison to } \\
\text { normotensive patients }\end{array}$ \\
\hline Kampoli et al. [106] & $\begin{array}{l}\text { Pioglitazone }(15 \mathrm{~m} / \text { day }) \\
\text { versus perindopril } \\
(4 \mathrm{mg} / \text { day }) \\
\end{array}$ & $\begin{array}{l}50 \text { patients with T2DM, } \\
\text { randomized trial }\end{array}$ & 1 month & No effect on EPC \\
\hline Sugiura et al. [96] & $\begin{array}{l}\text { Nifedipine SR } 20 \mathrm{mg} / \text { day } \\
\text { versus placebo }\end{array}$ & $\begin{array}{l}37 \text { hypertensive patients with stage I } \\
\text { hypertension, randomized trial }\end{array}$ & 4 weeks & $\begin{array}{l}\uparrow \mathrm{EPC} \text { count } \\
\uparrow \mathrm{EPC} \text { differentiation migration, } \\
\text { resistance to oxidative stress } \\
\uparrow \mathrm{FMD}\end{array}$ \\
\hline de Ciuceis et al. [97] & $\begin{array}{l}\text { Barnidipine } 20 \mathrm{mg} / \mathrm{day} \\
\text { versus } \\
\text { hydrochlorothiazide } \\
25 \mathrm{mg} / \text { day }\end{array}$ & $\begin{array}{l}29 \text { hypertensive patients with mild } \\
\text { essential hypertension, randomized } \\
\text { trial }\end{array}$ & 6 months & $\begin{array}{l}\uparrow \text { EPC count with barnidipine } \\
\text { No difference in RR reduction } \\
\text { observed between drugs }\end{array}$ \\
\hline
\end{tabular}

\section{Current Limitations and Future Perspectives}

The discovery of circulating endothelial progenitor cells has challenged current concepts about the genesis and treatment of atherosclerosis and has unveiled very wide experimental and clinical perspectives. With respect to prominent medical, social, and economic impact of diabetic cardiovascular complications, researchers and clinicians involved in diabetology should not remain indifferent to these novel findings.
Since their discovery in 1997, accumulating findings suggest that EPCs promote postnatal vasculogenesis in adults, important for vascular repair of the injured endothelium, opening the way for new therapies of cardiovascular diseases focused on EPCs.

Despite these encouraging prospects, there are still issues and limitations that need to be addressed [124].

A special challenge is that patient groups who would gain the greatest benefit from new EPC based clinical concepts, 
TABLE 3

\begin{tabular}{|c|c|c|c|c|}
\hline Reference & Study drug & Study population and design & $\begin{array}{l}\text { Study } \\
\text { duration }\end{array}$ & Study findings \\
\hline Chen et al. [109] & Gliclazide $30-90$ g/day & $\begin{array}{l}33 \text { patients with newly diagnosed } \\
\text { T2DM versus } \\
25 \text { nondiabetic patients in the } \\
\text { control group }\end{array}$ & 12 weeks & $\begin{array}{l}\uparrow \text { EPC count } \\
\uparrow \text { flow mediated dilatation } \\
\downarrow \text { some markers of oxidative } \\
\text { stress in study group }\end{array}$ \\
\hline Chen et al. [108] & $\begin{array}{l}\text { Gliclazide }(30-60 \mathrm{~g} / \text { day }) \\
\text { and metformin } \\
(250-1000 \mathrm{mg} / \text { day }) \\
\text { versus metformin } \\
(500-2500 \mathrm{mg} / \text { day })\end{array}$ & $\begin{array}{l}47 \text { patients with newly diagnosed } \\
\text { T2DM, randomized trial }\end{array}$ & 16 weeks & $\begin{array}{l}\text { more profound } \uparrow \mathrm{EPC} \text { count and } \\
\text { function with combination } \\
\text { treatment }\end{array}$ \\
\hline Liao et al. [107] & $\begin{array}{c}\text { Metformin } \\
(1700-2550 \mathrm{mg} / \text { day })\end{array}$ & $\begin{array}{l}46 \text { patients with newly diagnosed } \\
\text { T2DM versus } 51 \text { healthy controls }\end{array}$ & 16 weeks & $\begin{array}{l}\uparrow \text { EPC count in both groups } \\
\text { T2DM patients had a lower EPC } \\
\text { count throughout the study } \\
\uparrow \text { FMD changed in both groups }\end{array}$ \\
\hline Werner et al. [110] & $\begin{array}{l}\text { Pioglitazone } 45 \mathrm{mg} / \text { day } \\
\text { versus placebo }\end{array}$ & $\begin{array}{l}54 \text { patients without T2DM, with } \\
\text { stable CAD, randomized trial }\end{array}$ & 30 days & $\begin{array}{l}\uparrow \text { EPC count } \\
\uparrow \text { migratory activity of EPCs } \\
\uparrow \text { clonogenic potential of EPCs } \\
\text { after pioglitazone treatment }\end{array}$ \\
\hline Wang et al. [111] & Pioglitazone $30 \mathrm{mg} /$ day & $\begin{array}{l}24 \text { patients with } \mathrm{T} 2 \mathrm{DM} \text { receiving } \\
\text { pioglitazone versus } 12 \text { patients } \\
\text { with T2DM receiving } \\
\text { metformin, randomized trial }\end{array}$ & 8 weeks & $\begin{array}{l}\uparrow \text { EPC count and homing and } \\
\text { decreased } \downarrow \text { EPC apoptosis, } \\
\downarrow \text { hsCRP, } \downarrow \text { triglycerides, } \downarrow \text { LDL, } \uparrow \\
\text { HDL cholesterol, and } \uparrow \text { insulin } \\
\text { sensitivity after pioglitazone } \\
\text { treatment } \\
\text { No change in FMD }\end{array}$ \\
\hline Makino et al. [112] & $\begin{array}{l}\text { Pioglitazone } \\
\text { (15-30 mg/day) }\end{array}$ & 34 patients with T2DM & 24 weeks & $\begin{array}{l}\uparrow \text { EPC count } \\
\uparrow \text { adiponectin } \\
\downarrow \text { hsCRP }\end{array}$ \\
\hline Esposito et al. [113] & $\begin{array}{c}\text { Pioglitazone } \\
\text { (15-45 mg/day) versus } \\
\text { metformin } \\
(1000-2000 \mathrm{mg} / \text { day })\end{array}$ & $\begin{array}{l}110 \text { patients with newly } \\
\text { diagnosed T2DM, randomized } \\
\text { trial }\end{array}$ & 24 weeks & $\begin{array}{l}\text { More profound } \uparrow \text { EPC count } \\
\uparrow \text { weight } \\
\uparrow \mathrm{HDL} \\
\uparrow \text { adiponectin } \\
\downarrow \text { CRP } \\
\downarrow \text { triglycerides in patients } \\
\text { receiving pioglitazone }\end{array}$ \\
\hline Kampoli et al. [106] & $\begin{array}{l}\text { Pioglitazone }(15 \mathrm{~m} / \text { day }) \\
\text { versus perindopril } \\
\text { (4 mg/day) }\end{array}$ & $\begin{array}{l}50 \text { patients with T2DM, } \\
\text { randomized trial }\end{array}$ & 1 month & $\begin{array}{l}\text { No effect on EPC count } \\
\text { Improved markers of } \\
\text { inflammation and oxidative } \\
\text { stress }\end{array}$ \\
\hline Fadini et al. [114] & $\begin{array}{l}\text { Sitagliptin } 100 \mathrm{mg} / \mathrm{day} \\
\text { versus no additional } \\
\text { treatment }\end{array}$ & $\begin{array}{l}16 \text { patients with } \mathrm{T} 2 \mathrm{DM} \text { receiving } \\
\text { sitagliptin, } \\
16 \text { patients with } \mathrm{T} 2 \mathrm{DM} \text { with no } \\
\text { additional treatment, controlled, } \\
\text { nonrandomized trial }\end{array}$ & 4 weeks & $\begin{array}{l}\uparrow \mathrm{EPC} \text { count } \\
\uparrow \mathrm{SDF}-1 \alpha \text { in the study group }\end{array}$ \\
\hline Nakamura et al. [115] & $\begin{array}{l}\text { Sitagliptin }(50 \mathrm{~m} / \text { day }) \\
\text { versus voglibose } \\
(0,6 \mathrm{mg} / \text { day })\end{array}$ & $\begin{array}{l}66 \text { patients with T2DM, } \\
31 \text { patients with T2DM, receiving } \\
\text { sitagliptin, } \\
35 \text { patients with T2DM receiving } \\
\text { voglibose }\end{array}$ & 12 weeks & $\begin{array}{l}\uparrow \text { EPC count with sitagliptin } \\
\uparrow \text { FMD in both groups, no } \\
\text { difference between groups }\end{array}$ \\
\hline Fadini et al. [116] & $\begin{array}{l}\text { Insulin detemir versus } \\
\text { insulin glargine }\end{array}$ & $\begin{array}{l}42 \text { patients with T2DM and } \\
\text { macroangiopathy, randomized } \\
\text { crossover study }\end{array}$ & 6 months & $\begin{array}{l}\uparrow \text { EPC count increased between } \\
\text { month } 3 \text { and month } 6 \text { in both } \\
\text { groups } \\
\uparrow \text { weight gain and } \uparrow \\
\text { hypoglycemic events with } \\
\text { glargine }\end{array}$ \\
\hline
\end{tabular}


like diabetic patients, are the same in whom different problems with decreased EPC number and their dysfunction have been clearly demonstrated [124, 125]. This problem limits approaches based on EPCs isolation, cultivation, and autologous transplantation in diabetic patients. In fact, new insights on reduced EPC counts and EPC dysfunction in diabetic patients will maybe allow us to introduce diabetic osteomyelopathy as a new, but very important, diabetic chronic complication.

Therefore, it is necessary to put more efforts into understanding mechanisms of EPC dysfunction and then to design new strategies to improve EPC function ex vivo before therapeutic transplantation.

Similar problems face other groups of patients, like elderly people. EPCs derived from aged individuals also show a reduced capacity to proliferate, home into existing capillary networks, and enhance perfusion like in diabetic patients [124-126].

Another problem is how to obtain adequate numbers of those cells. Furthermore, every autologous delivery of cells inevitably involves a considerable time delay in treatment, due to the time needed for collection, identification, isolation, and then propagation of progenitors ex vivo [124].

Adverse effects of endothelial progenitor cell delivery may include microvascular embolism and unintended acceleration of pathological neovascularization in malignancies. Undirected growth and possible undesired pathological differentiation after transplantation of those cells may generate risks of late complication, like teratoma. In fact, vigorous differentiation and purification protocols are needed, and studies proving the long-term safety profile of progenitor cells are required before widespread use in humans [124].

It seems to be more likely that a greater impact on general health could have concepts focused on prophylactic measures like lifestyle changes and/or pharmacological interventions with drugs specially designed to address EPC proliferation, migration, and homing to injured vessels.

\section{Conclusion}

Studies have proven the prognostic significance of endothelial function, which is most often clinically demonstrated as the vasodilator response to various pharmacological or mechanical stimulations. Endothelial dysfunction may occur over time, progressing to atherosclerotic plaques and clinical apparent vascular disease.

Since endothelial injury and dysfunction precede clinically significant atherosclerotic vascular disease and play a role in its pathogenesis, the discovery of EPCs has provided a new concept of vascular disease as potentially preventable and curable, offering new strategies for medical intervention.

Since EPCs are of extreme importance for reendothelialization of the injured endothelium, promoting vascular repair may be an attractive therapuetic approach. Maintaining normal EPC numbers and function seems to be crucial in preventing cardiovascular diseases.

There are still unresolved questions and many challenges to face before EPC based therapies will be widely used, but even with contemporary medical interventions the number and function of EPC may be improved. This is especially important for patients with metabolic alterations such as compensatory hyperinsulinemia, impaired fasting glucose, and IGT, whose EPC number is decreased and function is impaired.

\section{Conflict of Interests}

The author declares that there is no conflict of interests regarding the publication of this paper.

\section{Acknowledgment}

This study received publication fee in the form of a grant from MSD.

\section{References}

[1] M. C. Riddle, "Glycemic control and cardiovascular mortality," Current Opinion in Endocrinology, Diabetes \& Obesity, vol. 18, no. 2, pp. 104-109, 2011.

[2] L. G. Mellbin, M. Anselmino, and L. Rydén, "Diabetes, prediabetes and cardiovascular risk," European Journal of Cardiovascular Prevention and Rehabilitation, vol. 17, supplement 1, pp. S9-S14, 2010.

[3] I. Martín-Timón, C. Sevillano-Collantes, A. Segura-Galindo, and F. J. del Cañizo-Gómez, "Type 2 diabetes and cardiovascular disease: have all risk factors the same strength?" World Journal of Diabetes, vol. 5, no. 4, pp. 444-470, 2014.

[4] R. Stöhr and M. Federici, "Insulin resistance and atherosclerosis: convergence between metabolic pathways and inflammatory nodes," Biochemical Journal, vol. 454, no. 1, pp. 1-11, 2013.

[5] M. M. Polovina and T. S. Potpara, "Endothelial dysfunction in metabolic and vascular disorders," Postgraduate Medicine, vol. 126, no. 2, pp. 38-53, 2014.

[6] Y. Imai, A. D. Dobrian, J. R. Weaver et al., "Interaction between cytokines and inflammatory cells in islet dysfunction, insulin resistance and vascular disease," Diabetes, Obesity and Metabolism, vol. 15, supplement 3, pp. 117-129, 2013.

[7] J. L. Johnson, "Emerging regulators of vascular smooth muscle cell function in the development and progression of atherosclerosis," Cardiovascular Research, vol. 103, no. 4, pp. 452-460, 2014.

[8] J. F. Bentzon, F. Otsuka, R. Virmani, and E. Falk, "Mechanisms of plaque formation and rupture," Circulation Research, vol. 114, no. 12, pp. 1852-1866, 2014.

[9] Z. Sun, "Atherosclerosis and atheroma plaque rupture: normal anatomy of vasa vasorum and their role associated with atherosclerosis," The Scientific World Journal, vol. 2014, Article ID 285058, 6 pages, 2014.

[10] A. Sannino, L. Brevetti, G. Giugliano et al., "Non-invasive vulnerable plaque imaging: how do we know that treatment works?" European Heart Journal_Cardiovascular Imaging, vol. 15, no. 11, pp. 1194-1202, 2014.

[11] J. E. Feig, "Regression of atherosclerosis: insights from animal and clinical studies," Annals of Global Health, vol. 80, no. 1, pp. 13-23, 2014.

[12] R. W. Wissler and D. Vesselinovitch, "Brief overview of the mounting evidence that atherosclerosis is both preventable and 
reversible," Journal of Clinical Apheresis, vol. 4, no. 2-3, pp. 52$58,1988$.

[13] P. Constantinides, "Overview of studies on regression of atherosclerosis," Artery, vol. 9, no. 1, pp. 30-43, 1981.

[14] P. S. S. Lee and K. K. Poh, "Endothelial progenitor cells in cardiovascular diseases," World Journal of Stem Cells, vol. 6, no. 3, pp. 355-366, 2014.

[15] L. Zhang and Q. Xu, "Stem/progenitor cells in vascular regeneration," Arteriosclerosis, Thrombosis, and Vascular Biology, vol. 34, no. 6, pp. 1114-1119, 2014.

[16] E. Mannarino and M. Pirro, "Endothelial injury and repair: a novel theory for atherosclerosis," Angiology, vol. 59, no. 2, supplement, pp. 69S-72S, 2008.

[17] C. Besler, C. Doerries, G. Giannotti, T. F. Lüscher, and U. Landmesser, "Pharmacological approaches to improve endothelial repair mechanisms," Expert Review of Cardiovascular Therapy, vol. 6, no. 8, pp. 1071-1082, 2008.

[18] K.-H. Yiu and H.-F. Tse, "Specific role of impaired glucose metabolism and diabetes mellitus in endothelial progenitor cell characteristics and function," Arteriosclerosis, Thrombosis, and Vascular Biology, vol. 34, no. 6, pp. 1136-1143, 2014.

[19] P. Rajendran, T. Rengarajan, J. Thangavel et al., "The vascular endothelium and human diseases," International Journal of Biological Sciences, vol. 9, no. 10, pp. 1057-1069, 2013.

[20] J. Xu and M. H. Zou, "Molecular insights and therapeutic targets for diabetic endothelial dysfunction," Circulation, vol. 120, no. 13, pp. 1266-1286, 2009.

[21] C. Aalkjær, D. Boedtkjer, and V. Matchkov, "Vasomotion-what is currently thought?" Acta Physiologica, vol. 202, no. 3, pp. 253269, 2011.

[22] J. E. Deanfield, J. P. Halcox, and T. J. Rabelink, "Endothelial function and dysfunction: testing and clinical relevance," Circulation, vol. 115, no. 10, pp. 1285-1295, 2007.

[23] R. H. Böger, “The pharmacodynamics of L-arginine," Alternative Therapies in Health and Medicine, vol. 20, no. 3, pp. 48-54, 2014.

[24] J. Lei, Y. Vodovotz, E. Tzeng, and T. R. Billiar, "Nitric oxide, a protective molecule in the cardiovascular system," Nitric Oxide, vol. 35, pp. 175-185, 2013.

[25] M. Félétou and P. M. Vanhoutte, "Endothelium-derived hyperpolarizing factor: where are we now?" Arteriosclerosis, Thrombosis, and Vascular Biology, vol. 26, no. 6, pp. 1215-1225, 2006.

[26] L. Stoner, M. L. Erickson, J. M. Young et al., "There's more to flow-mediated dilation than nitric oxide," Journal of Atherosclerosis and Thrombosis, vol. 19, no. 7, pp. 589-600, 2012.

[27] A. J. Donato, G. L. Pierce, L. A. Lesniewski, and D. R. Seals, "Role of NFkappaB in age-related vascular endothelial dysfunction in humans," Aging, vol. 1, no. 8, pp. 678-680, 2009.

[28] I. Sudano, S. Roas, and G. Noll, "Vascular abnormalities in essential hypertension," Current Pharmaceutical Design, vol. 17, no. 28, pp. 3039-3044, 2011.

[29] M. Pacurari, R. Kafoury, P. B. Tchounwou, and K. Ndebele, "The renin-angiotensin-aldosterone system in vascular inflammation and remodeling," International Journal of Inflammation, vol. 2014, Article ID 689360, 13 pages, 2014.

[30] R. Madonna and R. de Caterina, "Cellular and molecular mechanisms of vascular injury in diabetes-part II: cellular mechanisms and therapeutic targets," Vascular Pharmacology, vol. 54, no. 3-6, pp. 75-79, 2011.

[31] A. C. Roberts and K. E. Porter, "Cellular and molecular mechanisms of endothelial dysfunction in diabetes," Diabetes \& Vascular Disease Research, vol. 10, no. 6, pp. 472-482, 2013.
[32] M. M. Hartge, T. Unger, and U. Kintscher, "The endothelium and vascular inflammation in diabetes," Diabetes and Vascular Disease Research, vol. 4, no. 2, pp. 84-88, 2007.

[33] H. A. R. Hadi and J. A. Al Suwaidi, "Endothelial dysfunction in diabetes mellitus," Vascular Health and Risk Management, vol. 3, no. 6, pp. 853-876, 2007.

[34] P. Geraldes and G. L. King, "Activation of protein kinase C isoforms and its impact on diabetic complications," Circulation Research, vol. 106, no. 8, pp. 1319-1331, 2010.

[35] C. Manrique, G. Lastra, and J. R. Sowers, "New insights into insulin action and resistance in the vasculature," Annals of the New York Academy of Sciences, vol. 1311, no. 1, pp. 138-150, 2014.

[36] X. F. Liu, J. Q. Yu, R. Dalan, A. Q. Liu, and K. Q. Luo, "Biological factors in plasma from diabetes mellitus patients enhance hyperglycaemia and pulsatile shear stress-induced endothelial cell apoptosis," Integrative Biology, vol. 6, no. 5, pp. 511-522, 2014.

[37] L. Piconi, L. Quagliaro, R. Assaloni et al., "Constant and intermittent high glucose enhances endothelial cell apoptosis through mitochondrial superoxide overproduction," Diabetes/Metabolism Research and Reviews, vol. 22, no. 3, pp. 198203, 2006.

[38] A. Avogaro, M. Albiero, L. Menegazzo, S. de Kreutzenberg, and G. P. Fadini, "Endothelial dysfunction in diabetes: the role of reparatory mechanisms," Diabetes Care, vol. 34, supplement 2, pp. S285-S290, 2011.

[39] J. A. McClung, N. Naseer, M. Saleem et al., "Circulating endothelial cells are elevated in patients with type 2 diabetes mellitus independently of HbAlc," Diabetologia, vol. 48, no. 2, pp. 345-350, 2005.

[40] S. Nomura, "Dynamic role of microparticles in type 2 diabetes mellitus," Current Diabetes Reviews, vol. 5, no. 4, pp. 245-251, 2009.

[41] A. A. Alsheikh-Ali, G. D. Kitsios, E. M. Balk, J. Lau, and S. Ip, "The vulnerable atherosclerotic plaque: scope of the literature," Annals of Internal Medicine, vol. 153, no. 6, pp. 387-395, 2010.

[42] V. J. Dzau, M. Gnecchi, A. S. Pachori, F. Morello, and L. G. Melo, "Therapeutic potential of endothelial progenitor cells in cardiovascular diseases," Hypertension, vol. 46, no. 1, pp. 7-18, 2005.

[43] T. Asahara, A. Kawamoto, and H. Masuda, "Concise review: circulating endothelial progenitor cells for vascular medicine," Stem Cells, vol. 29, no. 11, pp. 1650-1655, 2011.

[44] T. Resch, A. Pircher, C. M. Kähler, J. Pratschke, and W. Hilbe, "Endothelial progenitor cells: current issues on characterization and challenging clinical applications," Stem Cell Reviews and Reports, vol. 8, no. 3, pp. 926-939, 2012.

[45] B. Özüyaman, P. Ebner, U. Niesler et al., "Nitric oxide differentially regulates proliferation and mobilization of endothelial progenitor cells but not of hematopoietic stem cells," Thrombosis and Haemostasis, vol. 94, no. 4, pp. 770-772, 2005.

[46] A. Zampetaki, J. P. Kirton, and Q. Xu, "Vascular repair by endothelial progenitor cells," Cardiovascular Research, vol. 78, no. 3, pp. 413-421, 2008.

[47] R. M. Cubbon, M. B. Kahn, and S. B. Wheatcroft, "Effects of insulin resistance on endothelial progenitor cells and vascular repair," Clinical Science, vol. 117, no. 5, pp. 173-190, 2009.

[48] R. C. Rennert, M. Sorkin, R. K. Garg, and G. C. Gurtner, "Stem cell recruitment after injury: lessons for regenerative medicine," Regenerative Medicine, vol. 7, no. 6, pp. 833-850, 2012.

[49] S.-W. Youn, S.-W. Lee, J. Lee et al., "COMP-Ang1 stimulates HIF- $1 \alpha$-mediated SDF-1 overexpression and recovers ischemic 
injury through BM-derived progenitor cell recruitment," Blood, vol. 117, no. 16, pp. 4376-4386, 2011.

[50] X. Liu, B. Duan, Z. Cheng et al., "SDF-1/CXCR4 axis modulates bone marrow mesenchymal stem cell apoptosis, migration and cytokine secretion," Protein and Cell, vol. 2, no. 10, pp. 845-854, 2011.

[51] S. Wassmann, N. Werner, T. Czech, and G. Nickenig, "Improvement of endothelial function by systemic transfusion of vascular progenitor cells," Circulation Research, vol. 99, no. 8, pp. e74e83, 2006.

[52] J. I. Rotmans, J. M. M. Heyligers, H. J. M. Verhagen et al., "In vivo cell seeding with anti-CD34 antibodies successfully accelerates endothelialization but stimulates intimal hyperplasia in porcine arteriovenous expanded polytetrafluoroethylene grafts," Circulation, vol. 112, no. 1, pp. 12-18, 2005.

[53] G. P. Fadini, S. Sartore, C. Agostini, and A. Avogaro, "Significance of endothelial progenitor cells in subjects with diabetes," Diabetes Care, vol. 30, no. 5, pp. 1305-1313, 2007.

[54] C. G. Egan, R. Lavery, F. Caporali et al., "Generalised reduction of putative endothelial progenitors and CXCR4-positive peripheral blood cells in type 2 diabetes," Diabetologia, vol. 51, no. 7, pp. 1296-1305, 2008.

[55] G. P. Fadini, S. Sartore, M. Schiavon et al., "Diabetes impairs progenitor cell mobilisation after hindlimb ischaemiareperfusion injury in rats," Diabetologia, vol. 49, no. 12, pp. 3075-3084, 2006.

[56] A. Aicher, C. Heeschen, and S. Dimmeler, "The role of NOS3 in stem cell mobilization," Trends in Molecular Medicine, vol. 10, no. 9, pp. 421-425, 2004.

[57] C. V. Desouza, F. G. Hamel, K. Bidasee, and K. O’Connell, "Role of inflammation and insulin resistance in endothelial progenitor cell dysfunction," Diabetes, vol. 60, no. 4, pp. 12861294, 2011.

[58] T. J. Rabelink, H. C. de Boer, E. J. P. de Koning, and A.J. van Zonneveld, "Endothelial progenitor cells: more than an inflammatory response?" Arteriosclerosis, Thrombosis, and Vascular Biology, vol. 24, no. 5, pp. 834-838, 2004.

[59] H. Tilg and A. R. Moschen, "Inflammatory mechanisms in the regulation of insulin resistance," Molecular Medicine, vol. 14, no. 3-4, pp. 222-231, 2008.

[60] R. Wolk, A. Deb, N. M. Caplice, and V. K. Somers, "Leptin receptor and functional effects of leptin in human endothelial progenitor cells," Atherosclerosis, vol. 183, no. 1, pp. 131-139, 2005.

[61] M. R. Schroeter, M. Leifheit, P. Sudholt et al., "Leptin enhances the recruitment of endothelial progenitor cells into neointimal lesions after vascular injury by promoting integrin-mediated adhesion," Circulation Research, vol. 103, no. 5, pp. 536-544, 2008.

[62] T. Thum, D. Fraccarollo, S. Thum et al., "Differential effects of organic nitrates on endothelial progenitor cells are determined by oxidative stress," Arteriosclerosis, Thrombosis, and Vascular Biology, vol. 27, no. 4, pp. 748-754, 2007.

[63] S. A. Sorrentino, F. H. Bahlmann, C. Besler et al., "Oxidant stress impairs in vivo reendothelialization capacity of endothelial progenitor cells from patients with type 2 diabetes mellitus: restoration by the peroxisome proliferator-activated receptor$\gamma$ agonist rosiglitazone," Circulation, vol. 116, no. 2, pp. 163-173, 2007.

[64] P. M. Humpert, R. Neuwirth, M. J. Battista et al., "SDF-1 genotype influences insulin-dependent mobilization of adult progenitor cells in type 2 diabetes," Diabetes Care, vol. 28, no. 4, pp. 934-936, 2005.
[65] P. M. Humpert, Z. Djuric, U. Zeuge et al., "Insulin stimulates the clonogenic potential of angiogenic endothelial progenitor cells by IGF-1 receptor-dependent signaling," Molecular Medicine, vol. 14, no. 5-6, pp. 301-308, 2008.

[66] S. Möbius-Winkler, A. Linke, V. Adams, G. Schuler, and S. Erbs, "How to improve endothelial repair mechanisms: the lifestyle approach," Expert Review of Cardiovascular Therapy, vol. 8, no. 4, pp. 573-580, 2010.

[67] K. A. Volaklis, S. P. Tokmakidis, and M. Halle, "Acute and chronic effects of exercise on circulating endothelial progenitor cells in healthy and diseased patients," Clinical Research in Cardiology, vol. 102, no. 4, pp. 249-257, 2013.

[68] J.-S. Wang, M.-Y. Lee, H.-Y. Lien, and T.-P. Weng, "Hypoxic exercise training improves cardiac/muscular hemodynamics and is associated with modulated circulating progenitor cells in sedentary men," International Journal of Cardiology, vol. 170, no. 3, pp. 315-323, 2014.

[69] U. Laufs, A. Urhausen, N. Werner et al., "Running exercise of different duration and intensity: effect on endothelial progenitor cells in healthy subjects," European Journal of Cardiovascular Prevention and Rehabilitation, vol. 12, no. 4, pp. 407-414, 2005.

[70] M. Sandri, V. Adams, S. Gielen et al., "Effects of exercise and ischemia on mobilization and functional activation of bloodderived progenitor cells in patients with ischemic syndromes: results of 3 randomized studies," Circulation, vol. 111, no. 25, pp. 3391-3399, 2005.

[71] M. Keith, M. A. Kuliszewski, C. Liao et al., "A modified portfolio diet complements medical management to reduce cardiovascular risk factors in diabetic patients with coronary artery disease," Clinical Nutrition, 2014.

[72] V. Spigoni, C. Lombardi, M. Cito et al., "N-3 PUFA increase bioavailability and function of endothelial progenitor cells," Food \& Function, vol. 5, no. 8, pp. 1881-1890, 2014.

[73] J. Turgeon, S. Dussault, F. Maingrette et al., "Fish oil-enriched diet protects against ischemia by improving angiogenesis, endothelial progenitor cell function and postnatal neovascularization," Atherosclerosis, vol. 229, no. 2, pp. 295-303, 2013.

[74] J. M. Fernández, D. Rosado-Álvarez, M. E. Da Silva Grigoletto et al., "Moderate-to-high-intensity training and a hypocaloric Mediterranean diet enhance endothelial progenitor cells and fitness in subjects with the metabolic syndrome," Clinical Science, vol. 123, no. 6, pp. 361-373, 2012.

[75] C. Marin, R. Ramirez, J. Delgado-Lista et al., "Mediterranean diet reduces endothelial damage and improves the regenerative capacity of endothelium," The American Journal of Clinical Nutrition, vol. 93, no. 2, pp. 267-274, 2011.

[76] B. Hibbert, T. Simard, F. D. Ramirez et al., "The effect of statins on circulating endothelial progenitor cells in humans: a systematic review," Journal of Cardiovascular Pharmacology, vol. 62, no. 5, pp. 491-496, 2013.

[77] M. Vasa, S. Fichtlscherer, K. Adler et al., "Increase in circulating endothelial progenitor cells by statin therapy in patients with stable coronary artery disease," Circulation, vol. 103, no. 24, pp. 2885-2890, 2001.

[78] N. del Papa, M. Cortiana, C. Vitali et al., "Simvastatin reduces endothelial activation and damage but is partially ineffective in inducing endothelial repair in systemic sclerosis," The Journal of Rheumatology, vol. 35, no. 7, pp. 1323-1328, 2008. 
[79] P. E. Westerweel, F. L. J. Visseren, G. R. Hajer et al., "Endothelial progenitor cell levels in obese men with the metabolic syndrome and the effect of simvastatin monotherapy vs. simvastatin/ezetimibe combination therapy," European Heart Journal, vol. 29, no. 22, pp. 2808-2817, 2008.

[80] A. E. P. Pesaro, C. V. Serrano Jr., M. Katz et al., "Increasing doses of simvastatin versus combined ezetimibe/simvastatin: effect on circulating endothelial progenitor cells," Journal of Cardiovascular Pharmacology and Therapeutics, vol. 18, no. 5, pp. 447-452, 2013.

[81] B. Hibbert, X. Ma, A. Pourdjabbar et al., "Pre-procedural Atorvastatin mobilizes endothelial progenitor cells: clues to the salutary effects of statins on healing of stented human arteries," PLoS ONE, vol. 6, no. 1, Article ID e16413, 2011.

[82] Ç. Baran, S. Durdu, K. Dalva et al., "Effects of preoperative short term use of atorvastatin on endothelial progenitor cells after coronary surgery: a randomized, controlled trial," Stem Cell Reviews and Reports, vol. 8, no. 3, pp. 963-971, 2012.

[83] T. Sobrino, M. Blanco, M. Pérez-Mato, M. Rodríguez-Yáñez, and J. Castillo, "Increased levels of circulating endothelial progenitor cells in patients with ischaemic stroke treated with statins during acute phase," European Journal of Neurology, vol. 19, no. 12, pp. 1539-1546, 2012.

[84] B. Huang, Y. Cheng, Q. Xie et al., "Effect of $40 \mathrm{mg}$ versus $10 \mathrm{mg}$ of atorvastatin on oxidized low-density lipoprotein, highsensitivity c-reactive protein, circulating endothelial-derived microparticles, and endothelial progenitor cells in patients with ischemic cardiomyopathy," Clinical Cardiology, vol. 35, no. 2, pp. 125-130, 2012.

[85] C. Spadaccio, F. Pollari, A. Casacalenda et al., "Atorvastatin increases the number of endothelial progenitor cells after cardiac surgery: a randomized control study," Journal of Cardiovascular Pharmacology, vol. 55, no. 1, pp. 30-38, 2010.

[86] A. M. Leone, S. Rutella, M. B. Giannico et al., "Effect of intensive vs standard statin therapy on endothelial progenitor cells and left ventricular function in patients with acute myocardial infarction: statins for regeneration after acute myocardial infarction and PCI (STRAP) trial," International Journal of Cardiology, vol. 130, no. 3, pp. 457-462, 2008.

[87] L. Lu, J.-Z. Zhou, L. Wang, and T.-X. Zhang, "Effects of Xuezhikang and Pravastatin on circulating endothelial progenitor cells in patients with essential hypertension," Chinese Journal of Integrative Medicine, vol. 15, no. 4, pp. 266-271, 2009.

[88] G. Paradisi, M. Bracaglia, F. Basile et al., "Effect of pravastatin on endothelial function and endothelial progenitor cells in healthy postmenopausal women," Clinical and Experimental Obstetrics and Gynecology, vol. 39, no. 2, pp. 153-159, 2012.

[89] D. Tousoulis, I. Andreou, M. Tsiatas et al., "Effects of rosuvastatin and allopurinol on circulating endothelial progenitor cells in patients with congestive heart failure: the impact of inflammatory process and oxidative stress," Atherosclerosis, vol. 214, no. 1, pp. 151-157, 2011.

[90] S. Erbs, E. B. Beck, A. Linke et al., "High-dose rosuvastatin in chronic heart failure promotes vasculogenesis, corrects endothelial function, and improves cardiac remodelingresults from a randomized, double-blind, and placebocontrolled study," International Journal of Cardiology, vol. 146, no. 1, pp. 56-63, 2011.

[91] O. Yoshida, T. Kondo, Y. Kureishi-Bando et al., "Pitavastatin, an HMG-CoA reductase inhibitor, ameliorates endothelial function in chronic smokers," Circulation Journal, vol. 74, no. 1, pp. 195-202, 2010.
[92] A. O. Spiel, F. B. Mayr, J. M. Leitner, C. Firbas, W. Sieghart, and B. Jilma, "Simvastatin and rosuvastatin mobilize Endothelial Progenitor Cells but do not prevent their acute decrease during systemic inflammation," Thrombosis Research, vol. 123, no. 1, pp. 108-113, 2008.

[93] M. Hristov, C. Fach, C. Becker et al., "Reduced numbers of circulating endothelial progenitor cells in patients with coronary artery disease associated with long-term statin treatment," Atherosclerosis, vol. 192, no. 2, pp. 413-420, 2007.

[94] C. Werner, M. Baumhäkel, K. K. Teo et al., "RAS blockade with $\mathrm{ARB}$ and ACE inhibitors: current perspective on rationale and patient selection," Clinical Research in Cardiology, vol. 97, no. 7, pp. 418-431, 2008.

[95] F. H. Bahlmann, K. De Groot, O. Mueller, B. Hertel, H. Haller, and D. Fliser, "Stimulation of endothelial progenitor cells: a new putative therapeutic effect of angiotensin II receptor antagonists," Hypertension, vol. 45, no. 4, pp. 526-529, 2005.

[96] T. Sugiura, T. Kondo, Y. Kureishi-Bando et al., "Nifedipine improves endothelial function: role of endothelial progenitor cells," Hypertension, vol. 52, no. 3, pp. 491-498, 2008.

[97] C. de Ciuceis, A. Pilu, D. Rizzoni et al., "Effect of antihypertensive treatment on circulating endothelial progenitor cells in patients with mild essential hypertension," Blood Pressure, vol. 20, no. 2, pp. 77-83, 2011.

[98] F. Cacciatore, G. Bruzzese, D. F. Vitale et al., "Effects of ACE inhibition on circulating endothelial progenitor cells, vascular damage, and oxidative stress in hypertensive patients," European Journal of Clinical Pharmacology, vol. 67, no. 9, pp. 877-883, 2011.

[99] J. Y. Sun, L. Zhai, Q. L. Li et al., "Effects of ACE inhibition on endothelial progenitor cell mobilization and prognosis after acute myocardial infarction in type 2 diabetic patients," Clinics, vol. 68, no. 5, pp. 665-673, 2013.

[100] T. Q. Min, C. J. Zhu, W. X. Xiang, Z. J. Hui, and S. Y. Peng, "Improvement in endothelial progenitor cells from peripheral blood by ramipril therapy in patients with stable coronary artery disease," Cardiovascular Drugs and Therapy, vol. 18, no. 3, pp. 203-209, 2004.

[101] E. Cangiano, J. Marchesini, G. Campo et al., "ACE inhibition modulates endothelial apoptosis and renewal via endothelial progenitor cells in patients with acute coronary syndromes," The American Journal of Cardiovascular Drugs, vol. 11, no. 3, pp. 189198, 2011.

[102] I. Porto, L. di Vito, G. L. de Maria et al., "Comparison of the effects of ramipril versus telmisartan on high-sensitivity C-reactive protein and endothelial progenitor cells after acute coronary syndrome," The American Journal of Cardiology, vol. 103, no. 11, pp. 1500-1505, 2009.

[103] F. Pelliccia, V. Pasceri, C. Cianfrocca et al., "Angiotensin II receptor antagonism with telmisartan increases number of endothelial progenitor cells in normotensive patients with coronary artery disease: a randomized, double-blind, placebocontrolled study," Atherosclerosis, vol. 210, no. 2, pp. 510-515, 2010.

[104] H. Tan, X. Li, W. Chen et al., "Effects of losartan on the mobilization of endothelial progenitor cells and improvement of endothelial function," Annals of Clinical and Laboratory Science, vol. 43, no. 4, pp. 402-406, 2013.

[105] R. Suzuki, N. Fukuda, M. Katakawa et al., "Effects of an angiotensin II receptor blocker on the impaired function of 
endothelial progenitor cells in patients with essential hypertension," The American Journal of Hypertension, vol. 27, no. 5, pp. 695-701, 2014.

[106] A.-M. Kampoli, D. Tousoulis, Z. Pallantza et al., "Comparable effects of pioglitazone and perindopril on circulating endothelial progenitor cells, inflammatory process and oxidative stress in patients with diabetes mellitus," International Journal of Cardiology, vol. 157, no. 3, pp. 413-415, 2012.

[107] Y.-F. Liao, L.-L. Chen, T.-S. Zeng et al., "Number of circulating endothelial progenitor cells as a marker of vascular endothelial function for type 2 diabetes," Vascular Medicine, vol. 15, no. 4, pp. 279-285, 2010.

[108] L.-L. Chen, Y.-F. Liao, T.-S. Zeng, F. Yu, H.-Q. Li, and Y. Feng, "Effects of metformin plus gliclazide compared with metformin alone on circulating endothelial progenitor cell in type 2 diabetic patients," Endocrine, vol. 38, no. 2, pp. 266-275, 2010.

[109] L.-L. Chen, F. Yu, T.-S. Zeng, Y.-F. Liao, Y.-M. Li, and H.-C. Ding, "Effects of gliclazide on endothelial function in patients with newly diagnosed type 2 diabetes," European Journal of Pharmacology, vol. 659, no. 2-3, pp. 296-301, 2011.

[110] C. Werner, C. H. Kamani, C. Gensch, M. Böhm, and U. Laufs, "The peroxisome proliferator-activated receptor- $\gamma$ agonist pioglitazone increases number and function of endothelial progenitor cells in patients with coronary artery disease and normal glucose tolerance," Diabetes, vol. 56, no. 10, pp. 26092615, 2007.

[111] C.-H. Wang, M.-K. Ting, S. Verma et al., "Pioglitazone increases the numbers and improves the functional capacity of endothelial progenitor cells in patients with diabetes mellitus," The American Heart Journal, vol. 152, no. 6, pp. 1051.e1-1051.e8, 2006.

[112] H. Makino, S. Okada, A. Nagumo et al., "Pioglitazone treatment stimulates circulating CD34-positive cells in type 2 diabetes patients," Diabetes Research and Clinical Practice, vol. 81, no. 3, pp. 327-330, 2008.

[113] K. Esposito, M. I. Maiorino, C. Di Palo et al., "Effects of pioglitazone versus metformin on circulating endothelial microparticles and progenitor cells in patients with newly diagnosed type 2 diabetes-a randomized controlled trial," Diabetes, Obesity and Metabolism, vol. 13, no. 5, pp. 439-445, 2011.

[114] G. P. Fadini, E. Boscaro, M. Albiero et al., "The oral dipeptidyl peptidase- 4 inhibitor sitagliptin increases circulating endothelial progenitor cells in patients with type 2 diabetes: possible role of stromal-derived factor-1 $\alpha$," Diabetes Care, vol. 33, no. 7, pp. 1607-1609, 2010.

[115] K. Nakamura, H. Oe, H. Kihara et al., "DPP-4 inhibitor and alpha-glucosidase inhibitor equally improve endothelial function in patients with type 2 diabetes: EDGE study," Cardiovascular Diabetology, vol. 13, no. 1, p. 110, 2014.

[116] G. P. Fadini, S. V. de Kreutzenberg, V. Mariano et al., "Optimized glycaemic control achieved with add-on basal insulin therapy improves indexes of endothelial damage and regeneration in type 2 diabetic patients with macroangiopathy: a randomized crossover trial comparing detemir versus glargine," Diabetes, Obesity and Metabolism, vol. 13, no. 8, pp. 718-725, 2011.

[117] F. Pistrosch, K. Herbrig, U. Oelschlaegel et al., "PPAR $\gamma$-agonist rosiglitazone increases number and migratory activity of cultured endothelial progenitor cells," Atherosclerosis, vol. 183, no. 1, pp. 163-167, 2005.

[118] H.-F. Zhang, L. Wang, H.-J. Yuan et al., "Ppar- $\gamma$ agonist pioglitazone prevents apoptosis of endothelial progenitor cells from rat bone marrow," Cell Biology International, vol. 37, no. 5, pp. 430-435, 2013.

[119] X. Xiao-Yun, M. Zhao-Hui, C. Ke, H. Hong-Hui, and X. YanHong, "Glucagon-like peptide-1 improves proliferation and differentiation of endothelial progenitor cells via upregulating VEGF generation," Medical Science Monitor, vol. 17, no. 2, pp. BR35-BR41, 2011.

[120] J. Papak and D. Kansagara, "Management of hyperglycemia in a hospitalized patient with diabetes mellitus and cardiovascular disease," The American Journal of Cardiology, vol. 110, no. 9, supplement, pp. 24B-31B, 2012.

[121] K. Strehlow, N. Werner, J. Berweiler et al., "Estrogen increases bone marrow-derived endothelial progenitor cell production and diminishes neointima formation," Circulation, vol. 107, no. 24, pp. 3059-3065, 2003.

[122] A. Iwakura, C. Luedemann, S. Shastry et al., "Estrogenmediated, endothelial nitric oxide synthase-dependent mobilization of bone marrow-derived endothelial progenitor cells contributes to reendothelialization after arterial injury," Circulation, vol. 108, no. 25, pp. 3115-3121, 2003.

[123] T. J. Povsic, S. S. Najjar, K. Prather et al., "EPC mobilization after erythropoietin treatment in acute ST-elevation myocardial infarction: the REVEAL EPC substudy," Journal of Thrombosis and Thrombolysis, vol. 36, no. 4, pp. 375-383, 2013.

[124] N. J. Leeper, A. L. Hunter, and J. P. Cooke, "Stem cell therapy for vascular regeneration: adult, embryonic, and induced pluripotent stem cells," Circulation, vol. 122, no. 5, pp. 517-526, 2010.

[125] G. Spinetti, N. Kraenkel, C. Emanueli, and P. Madeddu, "Diabetes and vessel wall remodelling: from mechanistic insights to regenerative therapies," Cardiovascular Research, vol. 78, no. 2, pp. 265-273, 2008.

[126] T. Asahara and A. Kawamoto, "Endothelial progenitor cells for postnatal vasculogenesis," The American Journal of PhysiologyCell Physiology, vol. 287, no. 3, pp. C572-C579, 2004. 


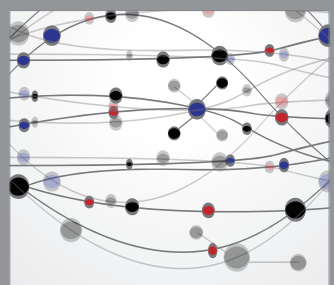

The Scientific World Journal
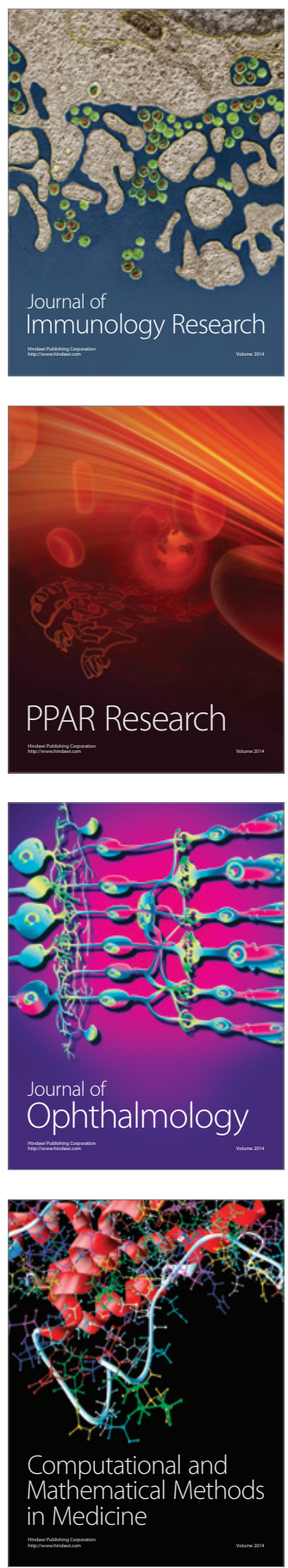

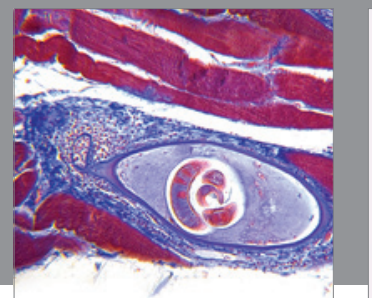

Gastroenterology

Research and Practice
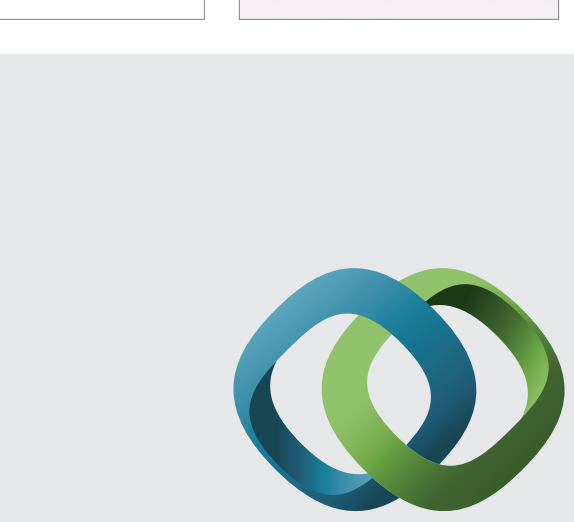

\section{Hindawi}

Submit your manuscripts at

http://www.hindawi.com
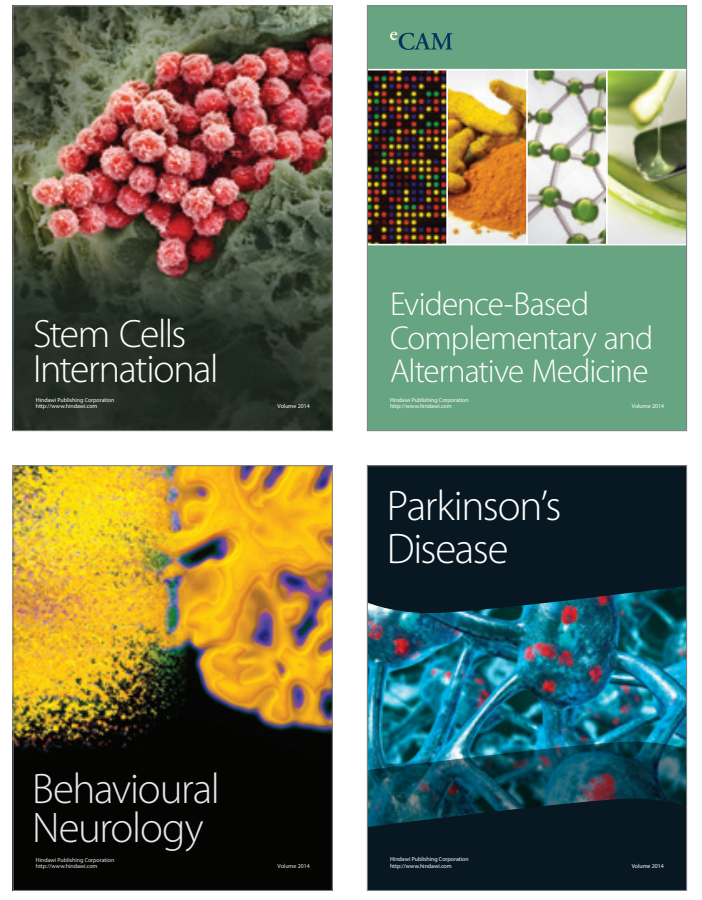
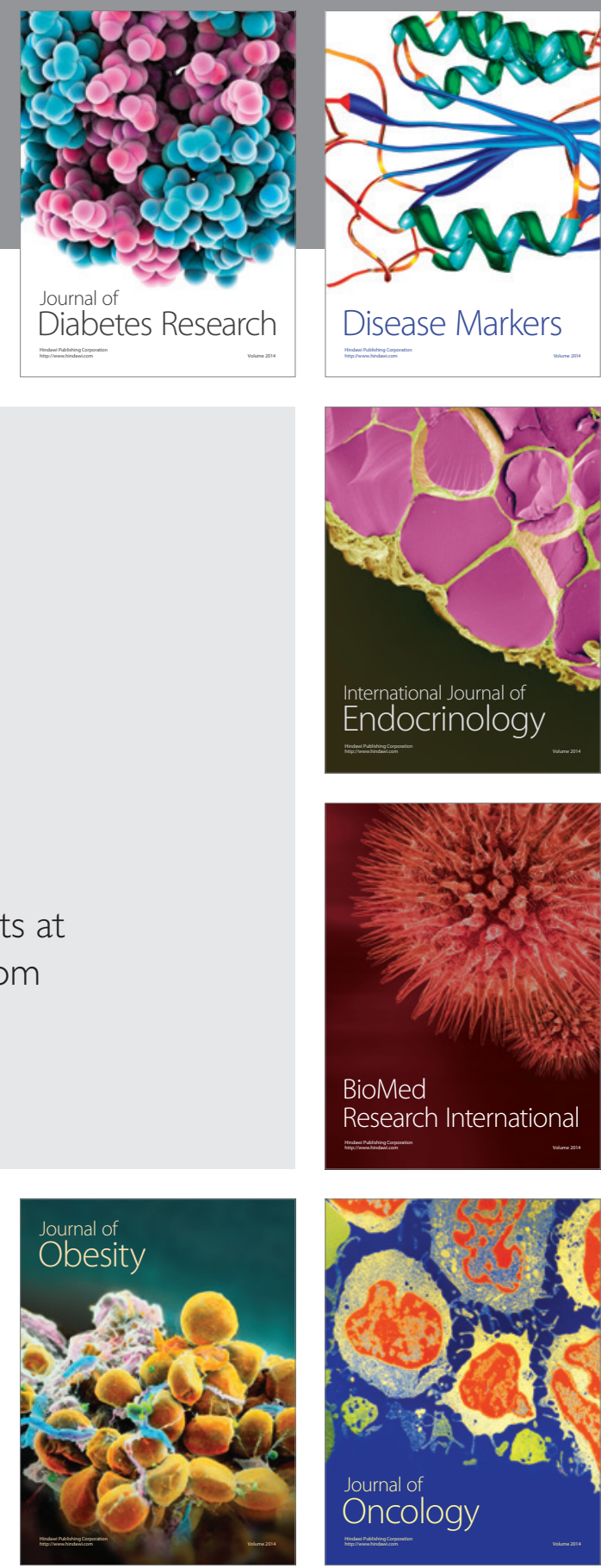

Disease Markers
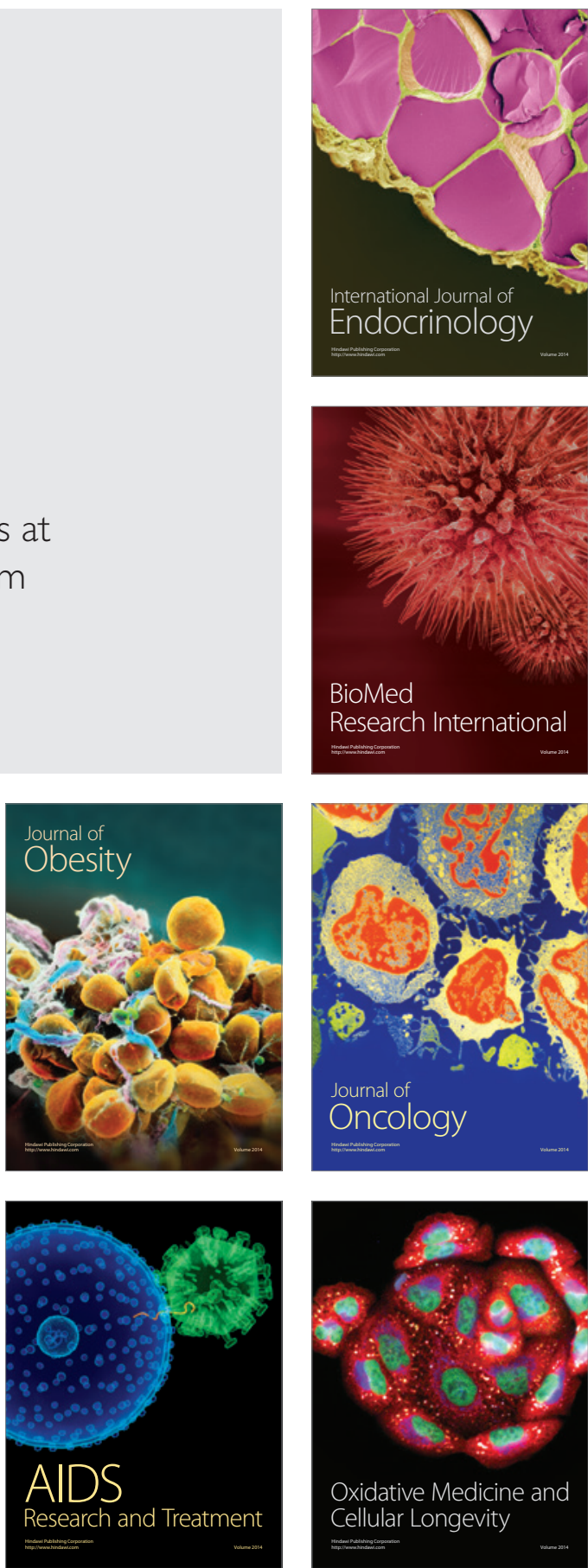